\title{
The Liberalization of Electricity Market in Russia
}

\author{
A. N. Melnik ${ }^{1} \&$ O. N. Mustafina ${ }^{1}$ \\ ${ }^{1}$ Kazan (Volga region) Federal University, Russian Federation \\ Correspondence: A. N. Melnik, Kazan (Volga region) Federal University, 18, Kremlyovskaya Street, Kazan \\ 420008, Repablic of Tatarstan, Russian Federation.
}

\author{
Received: April 19, 2014 Accepted: May 5, 2014 Online Published: June 25, 2014 \\ doi:10.5539/ass.v10n13p280 \\ URL: http://dx.doi.org/10.5539/ass.v10n13p280
}

\begin{abstract}
Until the early 90 's of the last century a vertically integrated monopoly structure was the main model of the organization of the power industry in most countries of the world. The quality of services and prices for electricity were regulated in different countries exclusively by the state authorities. However, it gradually became apparent that many of the positive features of the vertical integration, including in the first place "the impact of economies of scale," ceased to play a significant role. By this time, most of the advanced and developing countries, including Russia, have realized the objective need for a review of the existing principles of power industry organization through the introduction of market mechanisms of its functioning. The study gives the overview of the aims and objectives of the reforms in the Russian electric power industry. Of special interest is the analysis of the experience in the energy markets restructuring in advanced and developing countries. The stages and main features of the restructuring of Russian energy market are shown. The model of liberalization for electric power market in Russia is represented. Particular attention is paid to the development of competition in the different segments of wholesale and retail power markets.
\end{abstract}

Keywords: Russia, power market, restructuring, liberalization, competition

\section{Introduction}

By the beginning of the Russian power industry restructuring it has accumulated a large number of unresolved issues, significantly restricting the development of both the industry and the entire national economy. Among these problems are the rapid growth of consumer non-payment for supplied products, the lack of incentives for energy companies to improve the efficiency of production, lack of transparency in the operation of energy companies, the decline in investment in the energy sector and, as a result, an ever-increasing level of deterioration of generating capacity (Engoian, 2006; Kuleshov, Viljainen, Annala, \& Gore, 2012). All this has led to the fact that by the most important technological indexes, including specific fuel consumption for power generation, the average efficiency of the equipment, operating power of Russian energy companies stations significantly lag behind the foreign companies. The situation was exacerbated by rolling blackouts of electricity, systematically observed in some regions of the country, as well as by increasing probability of occurrence of major technological accidents at the power sites.

Under the conditions of the high degree of influence of the power industry on the performance of the entire Russian economy, a significant deterioration of the competitive positions of many of its branches, that felt the brunt of the energy companies development related problems, became natural. It found its expression in the level of energy intensity of gross domestic product of Russia, which was 3 or 4 times higher than the values of the same indicator for the developed world powers (Melnik \& Sadriev, 2013; Safiullin, Ismagilova, Safiullin, \& Bagautdinova, 2012; Bagautdinova, Murtazina, Fazlieva, \& Naida, 2013). In order to prevent further loss of competitiveness of the national economy and restore the positive dynamics of its most important infrastructure sector, it was decided to implement a large-scale restructuring in the power engineering.

\section{Method}

In the frame of the research context analysis method was used. It targets to examine not only the object of research, but also the context, which forms the external environment for its operation. The context in this case is defined as a system of internal and external factors affecting the functioning of the Russian electric power industry in terms of its liberalization. The internal context is a system of unique technological and economic Russian electricity sector characteristics and conditions, including goals, objectives, stages of reforms, as well as 
lining up system of relations between the different actors of energy industry during the liberalization process. The external context is a system of different socio-economic entities over which the electricity market liberalization had the effect, including a variety of businesses organizations and industrial enterprisers, as well as population. Understanding and treatment of the context within which the operation of these processes occurs allowed increasing the objectivity of the results of the study.

\section{Results}

\subsection{Experiences in the Energy Markets Restructuring in Advanced and Developing Countries}

Since the early 80 s almost all developed countries, including the U.S., Canada, UK, Germany and a number of other countries, have taken serious legislative and regulatory measures for the implementation of the gradual transition from state regulation of electricity and power market to the competitive pricing of energy products (Akkemik \& Oguz, 2011). For several reasons, this process began much later in Russia. Therefore, the liberalization of electricity and power market has been completed in this country by the beginning of 2011. By this time, the developed countries have already formed and developed mechanisms of management of energy systems in a competitive market.

The analysis of existing models of the organization of national energy markets revealed that in most countries of the world electric power was seen as an important strategic asset (Hay, 2009). Subsequently, it was supposed for a long time that the most effective management of such an asset can only be achieved when operated under a vertically integrated monopoly structure. Generally, the owner of such a structure was the state. However, in recent decades a vertically integrated model of the industry has demonstrated its significant limitations and for this reason has been revised by almost all countries using it (Nepal \& Jamasb, 2012; Panasyuk, Gafurov, \& Novenkova, 2013).

Perhaps the first serious attempt to liberalize the power market, according to some researchers (Markov, Bagautdinova, \& Yashin, 2013), was the founding of a competitive power market in Chile in 1980. Chilean government adopted measures aimed at creating the industry's system of market pricing to attract private investment into the energy companies and, as a result, reduce the tariffs for electric energy. The positive results of these reforms were observed by many countries which, following Chile, began to carry out similar reforms. Currently, a number of countries have power markets that are functioning successfully for a sufficiently long period of time. For example, in European countries a competitive power market first was formed in England and Wales in 1990. Norway's power market was organized in 1991. Other Nordic countries, including Sweden, Finland and Denmark, joined it in the second half of the 1990s (Eikeland, 1998; Johnsen \& Olsen, 2011; Juselius \& Stenbacka, 2011). The Australian National power market was liberalized in 1998. This process occurred at about the same time in New Zealand, but the formal establishment of the market in this country accounts for 1996 (Carstairs \& Pope, 2011).

In North America, a number of markets in the north-eastern states of the USA (power pool PJM) was launched at the end of the 1990s. California power market was formed in 1998 (Erdogdu, 2011). In the U.S. state of Texas and Canada free trade markets appeared later in 2001. In the early 90-s the process of liberalization of the energy markets affected many developing countries, including Poland, India, Thailand and other countries (Joseph, 2010; Glebova, Rodnyansky, \& Sadyrtdinov, 2013; Wang, 2006).

It should be noted that the choice of model for the organization of the power market in different countries and the effectiveness of its continued operation is defined, in our opinion, by the two main factors. First, by the objectives of restructuring of the power industry and, secondly, by the basic conditions of the structural changes in the industry.

The analysis of various sources revealed a significant differentiation of objectives and conditions for the restructuring of the power markets in developed and developing countries. It was established that the process of power markets liberalization in developed countries often took place with the general deregulation of their economies in the background. In this context, the main reason for the liberalization of electric power markets in the developed countries was, above all, the need to improve the economic indicators of the power companies.

However, the main stages of power industry restructuring were quite similar for most of the countries. They include:

- the development of legal framework for reform in the energy sector (power industry), which recognize the right for private property and the right for foreign investors to participate in the equity of energy (power) companies; 
- division of spheres of industrial activity on the competitive (generation and sale of electric energy) and exclusive (transportation and dispatching of electricity), the formation of a clear system of cost accounting in the power companies, the transfer of management of competing spheres to private owners;

- privatization of assets in the generation and sale of electric energy and the creation of a layer of independent producers of energy (power) products;

- $\quad$ creation of a competitive electricity market, which include the spot market and the market of forward contracts;

- the formation of mechanisms of market pricing, which compensate the expenses on the production and transmission of energy, the reduction and abolition of subsidies, improving collection rates for the electric power, provided to the consumers;

- the creation of an independent regulator in the industry with the necessary authority and appropriate methods to influence the power market participants.

\subsection{Goals and Objectives of Liberalization of the Russian Power Market}

The main goals of Russian power sector restructuring were to improve power companies efficiency, to create conditions for attracting large-scale investments in the sector and to ensure reliable and uninterrupted power supply to consumers. The transition of Russian power industry to a sustainable power development required solution for a number of important tasks, including:

- creation of competitive power markets in those regions of Russia, where the organization of such markets was technically possible;

- the development of an effective mechanism to reduce costs in the production, transmission and distribution of electricity;

- incentives for energy conservation in all sectors of the economy;

- creation of favorable conditions for the construction and operation of new facilities for the production and transmission of electric power;

- elimination of cross-subsidization between different groups of power consumers;

- creation of a system of targeted support for the poor people in the society;

- the preservation and development of a single electricity infrastructure, including the backbone network and dispatching;

- de-monopolization of the market of fuel for thermal power plants;

- the creation of the legal framework for restructuring of the industry, which can regulate its operation in the new economical conditions;

- restructuring of the system of state regulation, control and supervision over the electric power industry.

For the legal support and development of the legal framework of the process of restructuring the power industry were adopted federal laws "On Power Industry» (Russian Federation Law No. 35-FZ, 2003) and "On the Peculiarities of functioning of the electric power industry in the transition period» (Russian Federation Law No. 36-FZ, 2003) in 2003.

\subsection{Stages of the Restructuring of the Russian Power Market}

The restructuring has been divided into three phases, which ultimately suggested the creation of fundamentally new industry structure built around a fully-sufficient competitive wholesale power market.

At the first stage of restructuring regional vertically-integrated energy companies, being the monopolies in their areas of responsibility, were divided into generating, network and retail companies. Dispatching of the power flows began to be implemented by the state-controlled company - JSC "System Operator of the Unified Power System", with a network of branches in different parts of the country. The workout of the mechanisms of competitive market functioning was performed as a part of this phase of the restructuring and its infrastructure was formed.

As a result of the reforms, the industry was divided to natural monopoly activities-wise, including the transmission, power distribution and scheduling, as well as competitive power production and distribution. Thus, the originally existing territory-based and vertically integrated structures gave way to management companies formed according to their functioning criteria, i.e. depending on the particular type of activity. 
The privatization of large share of the generating, distribution and power services companies that were previously in the state domain allowed to attract significant amounts of investment needed for large-scale renovation of fixed assets and for the introduction of modern technologies in the working of power companies. The result of the implementation of these measures turned out to be a steady growth in the development of the new generating powers, the peak of which fell on 2011. The equipment, brought into service during this time, exceeded the ratings of the 2008-2009 for approximately 4.5 times (Fig. 1).

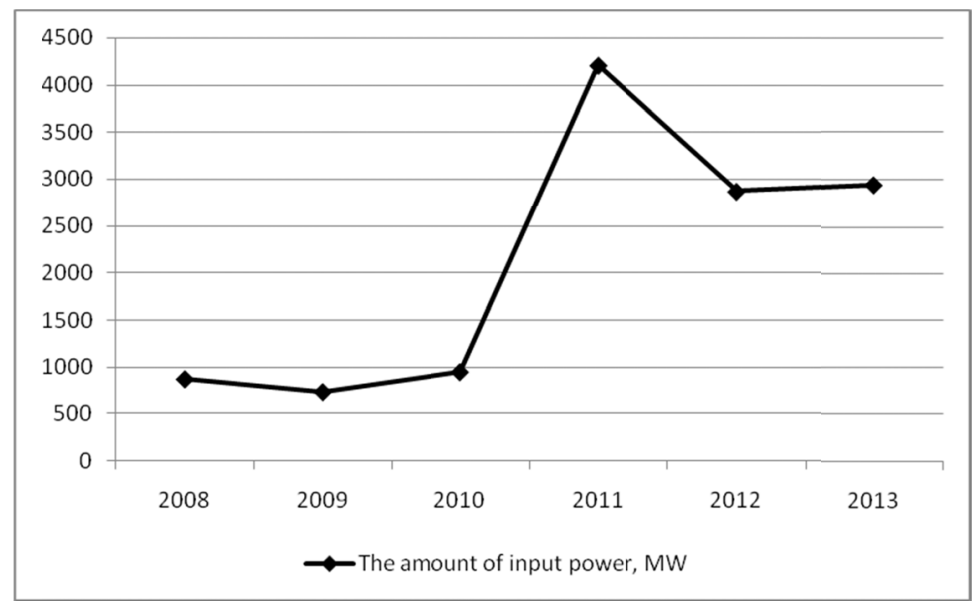

Figure 1. Changes in the commissioning of new capacity (Federal State Statistic Service of the Russian Federation)

At the second stage of restructuring regional generating and network companies were transformed into interregional companies, which combine core assets located in different parts of the country. Wholesale (WGC) and territorial (TGC) generating companies became participants in the wholesale power market. During that process, the WGCs combined power plant specializing in the production of electric energy, and the TGCs combined the heat and power plants, which also produce heat. Interconnections and high-voltage power lines have been merged into the Federal Network Company, which came to be under the control of the state. With the development of mechanisms of competitive pricing at the newly created market, the tariff based power trade was gradually replaced by the trade according to market prices (Table 1).

Table 1. The share of electrical power supplied at regulated tariffs in total production

\begin{tabular}{lc}
\multicolumn{1}{c}{ Period } & $\begin{array}{c}\text { The share of electric power supplied } \\
\text { at regulated tariff, } \%\end{array}$ \\
\hline from January $1^{\text {st }}$ to June $30^{\text {th }}$ in the year 2007 & $90-95$ \\
from July $1^{\text {st }}$ to December $31^{\text {st }}$ in the year 2007 & $85-90$ \\
from January $1^{\text {st }}$ to June $30^{\text {th }}$ in the year 2008 & $80-85$ \\
from July $1^{\text {st }}$ to December $31^{\text {st }}$ in the year 2008 & $70-75$ \\
from January $1^{\text {st }}$ to June $30^{\text {th }}$ in the year 2009 & $65-70$ \\
from July $1^{\text {st }}$ to December $31^{\text {st }}$ in the year 2009 & $45-50$ \\
from January $1^{\text {st }}$ to June $30^{\text {th }}$ in the year 2010 & $35-40$ \\
from July $1^{\text {st }}$ to December $31^{\text {st }}$ in the year 2010 & $15-20$ \\
from January $1^{\text {st }}$ in the year 2011 & 0 \\
\hline
\end{tabular}

The third stage has completed the formation of a competitive power market. From January $1^{\text {st }}, 2011$, the Russian electricity market became fully competitive; in other words, from that day the entire electrical energy began to be bought and sold in compliance with the rules of the competitive market. The only exception was made for the population, which will continue to pay the tariffs for the electric power regulated by the state, as it had been before. 


\section{Discussion}

\subsection{The Development of Competition in the Power Market}

The most important goal of liberalization of the Russian power market was the creation of the conditions necessary for the development of competition on it. Achieving this goal is largely determined by the efficiency of efforts to expand the number of participants in this market, including both producers and consumers of electrical energy (Wamukonya, 2004).

To date, the greatest achievements in terms of solutions of this problem are observed in the wholesale power market. By 2012, its subjects amounted to 374 organizations, including the generating and supply companies, as well as industrial companies (Sarkin, Bagautdinova, \& Averianov, 2013). It should be noted, that in the near future the number of participants in the wholesale market could increase significantly. There are more than 1,300 enterprises today in Russia, the average annual power consumption of which amounts to more than 100 million kilowatt-hours (Fig. 2). This level of consumption is the minimum requirement for consumers, which permits them to enter the wholesale power market. In other words, under favourable circumstances, the number of participants in the wholesale market could increase by more than 4 times, significantly increasing the intensity of competition on it.

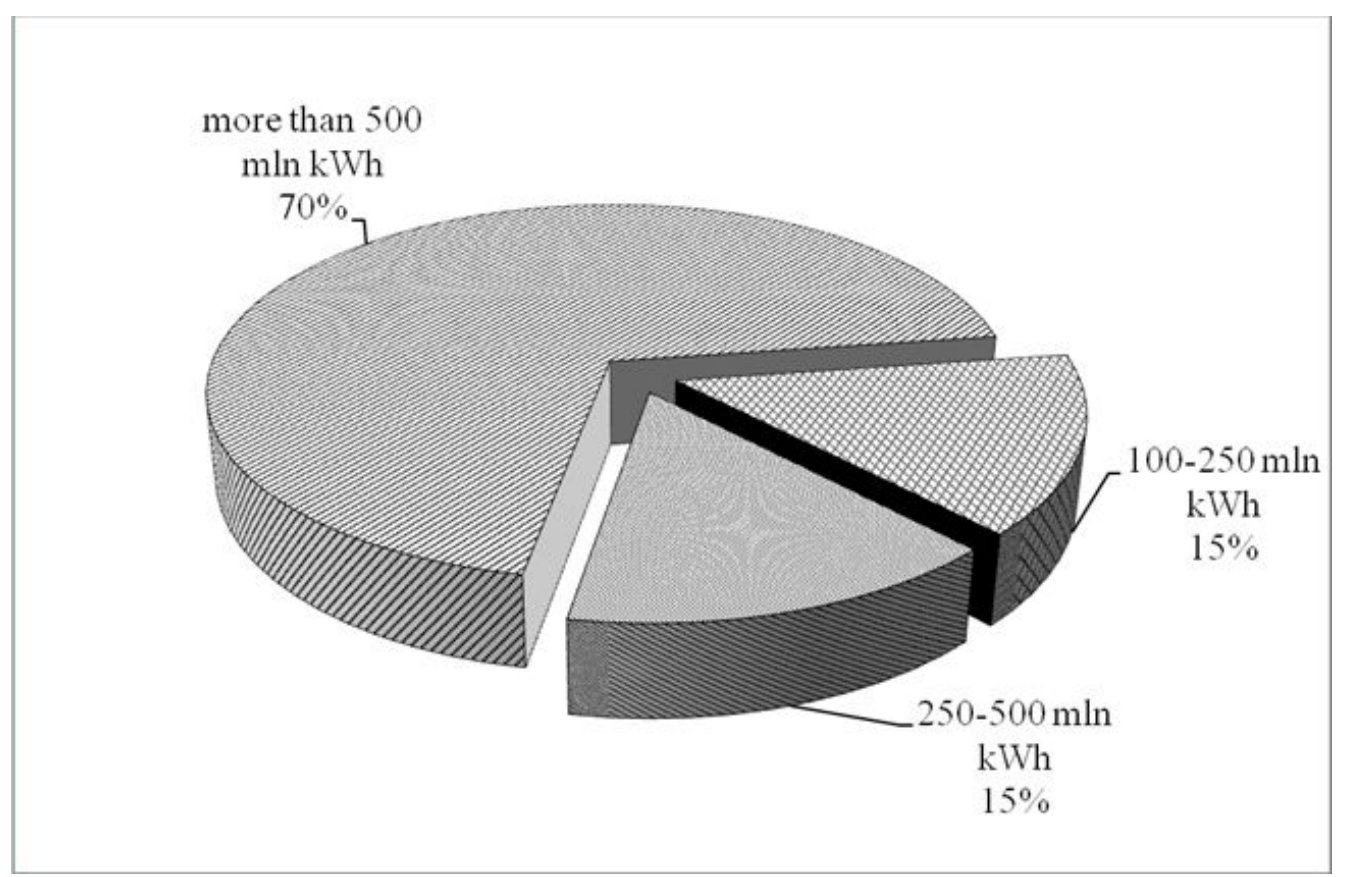

Figure 2. The allocation of the largest consumers in the Russian Federation in terms of power consumption (Federal State Statistic Service of the Russian Federation)

The development of competition in the retail power market is currently slower than expected. At the time, the choice of distribution companies in almost all regions of Russia is still quite limited. However, the situation is changing for the better.

Of the 720 registered in the Russian distribution (merchandise) companies, 363 have the status of a guaranteed supplier. If at the beginning of the reform the distribution companies with the status of a guaranteed supplier were, in most cases, a monopoly in its area of responsibility, today they gradually lose their dominant position. According to several studies over the past two years, such distribution companies have lost about $14 \%$ of its market share. At the same time, to maintain their position in the market could less than $10 \%$ of the guaranteed suppliers.

Nevertheless, in many regions choice between supply companies still remains limited. Most often, the regional markets offer two, at best three distribution companies. Thus, in 15 regions of Russia customer service is maintained by two domestic companies, in 8 - by three distribution companies, in 3 - by four distribution companies. 


\subsection{Outcomes of the Liberalization of the Power Market}

To date, the power market has almost fully formed the new conditions for increasing the efficiency of energy resources' consumption. They are based not only on the implementation of the internal reserves of power saving, but also upon the use of additional features, provided to consumers of power products by the competitive power market. Thus, liberalization of the Russian power market has had a very significant impact upon the enterprises in the industry, empowering them with new tools to enhance their own competitiveness.

It should be noted that the process of liberalization of the power market can be viewed from different perspectives. First, offered by the liberalized power market strategy forming opportunities and behavioral tactics on it, including, above all, the possibility of choosing a power supplier, permit to attribute the market to the factors of the microenvironment. In this context, the power market can be seen as an integral infrastructure element in the functioning of the industrial enterprises.

Undertaken liberalization can be seen from the other side. At the signing of the free contracts the enterprise directly interacts with the power supplier. And the companies already present on the wholesale power market, have received an opportunity to choose, firstly, the segment of the market for power purchasing, including the day-ahead market, the market of free bilateral contracts, power exchange; secondly, a supplier of power energy and thirdly, the type of contract for power supply. Enterprises functioning in the retail power market, have received the choice of the marketing company and the terms of cooperation with it. In other words, the liberalization of the power market allowed to engage the companies in the process of actively choosing their most preferred power supply alternatives for their own production and economic activities.

Secondly, the successful implementation of the above allows to consider a system of power supply as a source of competitive advantage of the enterprise (Melnik, Lukishina, \& Khabibrakhmanov, 2013). In the changed conditions, the power strategy of the enterprise takes on a special significance. Now, it may cover several objectives, including providing the industrial and economic activities with the necessary power resources at competitive prices, insuring from possible fluctuations in the power, as well as obtaining additional income through the commission from various operations in the power market.

Thirdly, the liberalization of the power market can also be seen as a risk factor for all its participants. The reason for that lays in the fact, that the competition, as a rule, always increases the uncertainty of behavior of the environment. For businesses, this is expressed primarily in the unstable dynamics of the power prices and in the complexity of its prediction. It should also be taken into account, that there are risks arising from the sale of excess volume of power consumption, obtained through a bilateral agreement at the market pricing and for a day ahead, which may be lower than the agreement price. The same applies to the possible deviations during purchase or sale from the planned power consumption in the balancing market.

\section{Conclusions}

As a result of restructuring of the power industry, a transition from a monopoly to a competitive structure of the power came. There was established a wholesale and a retail power markets. Developed regulations of their functioning, forming the requirements for market participants and the rules for their behavior.

Summarizing achieved results in the implementation of structural reforms in the power industry, the following should be emphasized. Completion by early 2011 of the active phase of liberalization of the power market has finally secured a fundamental change in the basis of the operation of the power companies and industrial enterprises. Formally, from this time began a new phase in their relations with all other branches and spheres of the national economy, the format of which was based on the full market basis. Since the beginning of 2011 all the electrical energy in the country began to be sold at competitive prices. The only exceptions were made for the population, and some other equated consumers. The use of competitive pricing mechanism for power products became an important factor, influencing the cost reduction for many of its producers.

\section{References}

Akkemik, K. A., \& Oguz, F. (2011). Regulation, efficiency and equilibrium: A general equilibrium analysis of liberalization in the Turkish electricity market. Energy, (36), 3282-3292. http://dx.doi.org/10.1016/ j.energy.2011.03.024

Bagautdinova, N. G., Murtazina, G. R., Fazlieva, E. P., \& Naida, A. M. (2013). Improvement of the regional management system using the labor potential index. World Applied Sciences Journal, 27(1), 107-111.

Carstairs, J., \& Pope, I. (2011). The case for a new capacity mechanism in the UK electricity market-Lessons from Australia and New Zealandn. Energy Policy, (39), 5096-5098. http://dx.doi.org/10.1016/j.enpol. 


\subsubsection{4}

Eikeland, P. O. (1998). Electricity market liberalisation and environmental performance: Norway and the UK. Energy Policy, (26), 917-927. http://dx.doi.org/10.1016/S0301-4215(98)00035-4

Engoian, A. (2006). Industrial and institutional restructuring of the Russian electricity sector: Status and issues. Energy Policy, (34), 3233-3244. http://dx.doi.org/10.1016/j.enpol.2005.06.008

Erdogdu, E. (2011). The impact of power market reforms on electricity price-cost margins and cross-subsidy levels: A cross country panel data analysis. Energy Policy, (39), 1080-1092. http://dx.doi.org/10.1016/ j.enpol.2010.11.023

Federal State Statistic Service of the Russian Federation. Retrieved from http:/www.gks.ru

Glebova I. S., Rodnyansky, D., Sadyrtdinov, R., Khabibrakhmanova, R., \& Yasnitskaya, Y. (2013). Evaluation of Corporate Social Responsibility of Russian Companies Based on Nonfinancial Reporting. Middle-East Journal of Scientific Research, 13(Socio-Economic Sciences and Humanities), 143-148,.

Hay, J. L. (2009). Challenges to liberalism: The case of Australian energy policy. Resources Policy, (34), 142-149. http://dx.doi.org/10.1016/j.resourpol.2008.05.001

Johnsen, T. A., \& Olsen, O. J. (2011). Regulated and unregulated Nordic retail prices. Energy Policy, (39), 3337-3345. http://dx.doi.org/10.1016/j.enpol.2011.03.027

Joseph, K. L. (2010). The politics of power: Electricity reform in India. Energy Policy, (38), 503-511. http://dx.doi.org/10.1016/j.enpol.2009.09.041

Juselius, M., \& Stenbacka, R. (2011). The Relevant Market for Production and Wholesale of Electricity in the Nordic Countries: An Econometric Study. Scandinavian Journal of Economics, (113), 167-189. http://dx.doi.org/10.1111/j.1467-9442.2010.01640.x

Kuleshov, D., Viljainen, S., Annala, S., \& Gore, O. (2012). Russian electricity sector reform: Challenges to retail competition. Utilities Policy, (23), 40-49. http://dx.doi.org/10.1016/j.jup.2012.05.001

Markov, V. A., Bagautdinova, N. G., \& Yashin, N. S. (2013). Improvement of instruments of the state cluster-based policy in the contexts of economic entities interrelation asymmetry. World Applied Sciences Journal, 27(13), 130-134.

Melnik A. N., Lukishina L. V., \& Khabibrakhmanov, R. R. (2013). Methodological Foundations of the Formation of the Energy Strategy of an Enterprise. World Applied Sciences Journal, 23(8), 1085-1089.

Melnik, A. N., \& Sadriev A. R. (2013). Problems and prospects of the formation of clusters in the power engineering. World Applied Sciences Journal (Education, Law, Economics, Language and Communication), (27), 194-197.

Nepal, R., \& Jamasb, T. (2012). Restructuring the power sector in transition: Do institutions matter? Energy Economics, (34), 1675-1682. http://dx.doi.org/10.1016/j.eneco.2012.02.002

Panasyuk, M. V., Gafurov, I. R., \& Novenkova, A. Z. (2013). Influence of international transport and logistics systems on economic development of the region. World Applied Sciences Journal, 27(13), 135-139.

Safiullin L. N., Ismagilova, G. N., Safiullin, N. Z., \& Bagautdinova N. G. (2012). The development of welfare theory in conditions of changes in the quality of goods and services. World Applied Sciences Journal, 18(Special Issue of Economics), 144-149.

Sarkin, A. V., Bagautdinova, N. G., \& Averianov, B. A. (2013). Development and implementation of adaptive science-intensive manufacture management system based on management processes automation. World Applied Sciences Journal, 27(13), 159-164.

Wamukonya, N. (2004). Power sector reform in developing countries: Mismatched agendas. Energy Policy, (32), 941-941. http://dx.doi.org/10.1016/S0301-4215(03)00181-2

Wang, K. M. (2006). The deregulation of Taiwan electricity supply industry. Energy Policy, (34), 2509-2520. http://dx.doi.org/10.1016/j.enpol.2004.08.020

\section{Copyrights}

Copyright for this article is retained by the author(s), with first publication rights granted to the journal.

This is an open-access article distributed under the terms and conditions of the Creative Commons Attribution license (http://creativecommons.org/licenses/by/3.0/). 